\title{
Atividade e Condição Humana em Hannah Arendt
}

\author{
[HUMAN CONDITION AND ACTIVITY IN HANNAH ARENDT]
}

\author{
Romildo Gomes Pinheiro * \\ Universidade do Estado de Mato Grosso, Brasil
}

\begin{abstract}
Resumo: Gostaríamos de demonstrar neste ensaio que é possível estabelecermos uma relação de proximidade entre Arendt e Marx acerca dos conceitos de "vida activa" e "condição humana", a despeito das críticas de Arendt à Marx na obra $A$ Condição Humana. Sustentaremos que Marx e Arendt partem de uma concepção do homem como um ser ativo. Arendt se ancora no conceito de energeia em Aristóteles, e Marx no conceito de "atividade" do Idealismo Alemão. Ambos procuram ultrapassar o predomínio da contemplação sobre a ação. Além deste pressuposto comum, Marx, ao contrário do que diz Arendt, mas em acordo com sua perspectiva, estabelece uma distinção entre "obra", associada ao trabalho útil produtor de valor de uso, e trabalho, pensado não como metabolismo com a natureza, como diz Arendt, mas como trabalho sob as condições capitalistas de produção. Com efeito, argumentamos que a ideia de ser ativo na sua tripla articulação com a obra, o trabalho e a ação teorizada por Arendt, prolonga a perspectiva de Marx. Sob esta ótica, o conceito de inversão, isto é, a reversão da hierarquia entre contemplação e ação, é fundamental para determinados o quanto Arendt prolonga a perspectiva de Marx.
\end{abstract}

Palavras Chave: Arendt; condição humana; vida activa; Marx
ABSTRACT: We would like to demonstrate in this essay that it is possible to establish a relationship between Arendt and Marx about the concepts of "active life" and "human condition", despite Arendt's criticism of Marx in The Human Condition. We will argue that Marx and Arendt depart from a conception of man as an active being. Arendt is anchored in the concept of "energeia" in Aristotle, and Marx in the concept of "activity" of German Idealism. Both seek to overcome the predominance of contemplation over action. In addition to this common assumption, Marx, contrary to what Arendt says, but according to his perspective, establishes a distinction between "work", associated with useful work producing value of use, and work, thought not as metabolism with nature, as Arendt says, but as work under capitalist conditions of production. In fact, we argue that the idea of being active in its triple articulation with the work, work and the action theorized by Arendt prolongs Marx's perspective. From this perspective, the concept of inversion, that is, the reversal of the hierarchy between contemplation and action, is fundamental for certain how much Arendt prolongs Marx's perspective.

KEYWORDS: Arendt; human condition; vida activa; Marx

* Doutorado em Filosofia pela Universidade Federal da Paraíba (2012), com estágio no Centre de Philosophie du Droit (UCL), 2009-2011. Possui Pós-doutorado em Filosofia na Université Catholique de Louvain no Centre de Philosophie du Droit (2012-2014) e no Centre Europé (2014), e no Programa de Pós-Graduação em Sociologia da Universidade Federal do Piauí (2015-2017).E-mail: romildogp81@yahoo.com.br 


\section{INTRODUÇÃO. (PARTE 1)}

Gostaríamos de demonstrar neste ensaio que é possível estabelecermos uma relação de proximidade entre Arendt e Marx acerca dos conceitos de "vida activa" e "condição humana", a despeito das críticas de Arendt à Marx na obra $A$ Condição

170 Humana (doravante, $\mathrm{CH}, 2014)$. Sustentaremos que Marx e Arendt partem de uma concepção do homem como um ser ativo. Arendt se ancora no conceito de energeia em Aristóteles, e Marx no conceito de "atividade" do Idealismo Alemão. Ambos procuram ultrapassar o predomínio da contemplação sobre a ação. Além deste pressuposto comum, Marx, ao contrário do que diz Arendt, mas em acordo com sua perspectiva, estabelece uma distinção entre "obra", associada ao trabalho útil produtor de valor de uso, e trabalho, pensado não como metabolismo com a natureza, como diz Arendt, mas como trabalho sob as condições capitalistas de produção. Com efeito, argumentamos que a ideia de ser ativo na sua tripla articulação com a obra, o trabalho e a ação teorizada por Arendt, prolonga a perspectiva de Marx, apesar da divergência fundamental sobre a relação entre política e necessidades humanas, teorizada por ambos em termos de inversão. Ora, sobre o conceito de inversão, a reversão da hierarquia entre contemplação e ação é fundamental para determinarmos o quanto Arendt prolonga a perspectiva de Marx, ao conceder uma primazia à ação comum, à ação revolucionária, sobre as condições de existência. Todavia, antes de avançarmos esta conclusão, é igualmente importante examinarmos a relação entre Arendt e Marx com o conceito de condição humana, pois que, do mesmo modo que com a categoria da práxis, nós podemos constatar uma correspondência profunda entre as duas análises. Para tanto, partindo de Arendt, nós retornaremos as análises de Heidegger sobre o mundo cotidiano, pois é nesta relação que nós podemos compreender a relevância que Arendt concede ao conceito de "condição", o outro polo da práxis humana. Sua gênese explicativa do conceito de "condição" se opera a partir da referência aos conceitos de obra, instrumento e uso. Mas aqui as coisas também se complicam. Arendt crítica a oposição em Ser e Tempo entre a resolução do si-mesmo (autenticidade) e o domínio do Impessoal (inautenticidade) que rege o mundo da vida cotidiana, oposição esta que demonstra o quanto o agir situado do si-mesmo permanece ainda determinado pelo primado do bios teoretikos, pois que constituído pela sua separação intrínseca do mundo da coexistência cotidiana. Sob este ponto, a referência a Aristóteles é decisiva para examinarmos as posições de Arendt e Heidegger, pois tanto em $\mathrm{CH}$ quanto em Ser e Tempo nós encontramos uma apropriação da práxis em Aristóteles. Por fỉm, armada esta relação comparativa, nossa perspectiva consistirá em articular o modo como Arendt em $\mathrm{CH}$, de maneira pioneira, dialoga criticamente não só com Heidegger, como já foi igualmente sublinhado por alguns comentadores, como Jacques Taminiaux e Danna Villa (TAMINIAUX, 1991, VILA, D. 1996), mas também, e fundamentalmente, com Marx. A nosso ver, assinalar esta relação com Marx implica em demonstrar o quanto a originalidade de $\mathrm{CH}$ se tece pela relação que Arendt estabelece com Heidegger e Marx, e não somente com Heidegger, como é o caso dos comentadores precedentes. Através desta moldura teórica, nossa conclusão consiste em demonstrar como Arendt critica Marx a partir de Heidegger e Aristóteles, mas que, ao final, relida após a crítica dirigida a estes autores, o primado da práxis sobre as condições de existência em Arendt se aproxima muito mais de Marx do que de Heidegger. Para tanto, é necessário retornar ao texto de Marx além das críticas de Arendt, com o propósito de assinalar aquilo que há de comum ali onde se estabelece uma oposição. Ao final, é a própria perspectiva política de Arendt que readquire sentido à luz desta comparação, pois nosso objetivo final é retornar à Marx com o fito de superar a dualidade entre política e condição humana em Arendt.

\section{A INFLUÊnCIA FUNDAdORA De ARISTÓteles No CONCEITO DE VIDA ACTIVA EM A CONDIÇÃO HUMANA}

Examinemos em primeiro lugar o recurso de Arendt ao conceito de energeia em 
Aristóteles para formular o conceito de vita activa na obra $\mathrm{CH}$. Nós sabemos que Aristóteles designa o aspecto ativo do homem pelo termo "energeia". "Energos" significa "ser ativo" ou "estar em trabalho". Por "ergon", Aristóteles designa a "atividade", no sentido de fazer algo, mas também o "trabalho" no sentido de resultado ou produto acabado. Acorda que a etimologia do termo energeia provem de ergon, que corresponde de maneira geral ao sentido do termo atividade. Este termo tem um significado preciso, e está presente tanto na Metafísica quanto na Ética a Nicômaco e mesmo na Física. No Livro 9 da Metafísica, Aristóteles opõe "atividade" (energeia) e movimento (kinesis) como duas formas de mudanças. Movimento difere da atividade: no movimento, há uma separação entre o meio e o fim, em referência ao qual as ações são realizadas ou performadas, e os meios para atingir isso. Em atividade o fim é presente de forma imanente, não havendo separação entre meios e fins. Diferente do movimento, a atividade não tem por consequência em nenhuma parte, desde que meios e fins formam uma unidade indivisível (ROCKMORE, 1980, p. 63). O que significa que a atividade deve ser descrita na forma da relação entre potencialidade e atualidade: uma vez que a atividade possui um telos, um potencial a ser desdobrado e o resultado a ser obtido. A potencialidade (dynamis) é a possibilidade que é realizada ou tornase factual através da atividade. Deste modo, a possibilidade é a condição da atividade, de modo que a atividade é indissociável do resultado, onde, enfim, meios e fins formam uma unidade.

Antes de retomar diretamente o conceito de energeia, nos seus capítulos iniciais que antecedem a descrição das atividades humanas - fabricação, trabalho e ação -, o conceito de vida activa é equiparado a pólis ateniense e sua oposição à família regida pelo pater famile sobre a mulher e o escravo. Nesta descrição, a teoria política de Aristóteles constitui apenas a expressão teórica da sobreposição do cidadão livre sobre o escravo que reproduz com seu corpo as necessidades da espécie. Na Política, Aristóteles escreve que "a natureza", "quer tornar diferentes o corpo dos homens livres com relação àquele dos escravos, tornando este mais forte para o uso necessário, e o primeiro, por sua vez, ereto de estatura e incapaz para esse tipo de obras e adequado à vida política... mas acontece muitas vezes o oposto, e alguns têm só o corpo dos livres, e outros, a alma. É evidente que, se os homens livres fossem diferentes quanto ao corpo como são as estátuas dos deles, conviria a todos que aqueles que são inferiores mereçam servi-los como escravos. E, se isso é verdade para o corpo, seria ainda mais justo afirma-lo a respeito da alma; mas não é tão fácil ver a beleza da alma quanto é ver a do corpo.” (Aristóteles, Política, 2000, 1254b) Para Arendt, é nos homens livres que nós encontramos a vida activa com uma vida dedicada aos assuntos públicospolíticos com ênfase na ação ou práxis, identificada como o modo de expressão do bios politikos. Nem a obra (ergon) e nem o trabalho faziam parte deste modo de vida humano e autêntico, no qual não servia nem o que era necessário e nem o que era útil. É o bios politikos que expressa propriamente um modo de vida autônomo e autenticamente humano, em oposição ao modo de vida do escravo. Segundo Arendt, para Aristóteles são três os modos de vida em que os homens são livres, independente, portanto, das necessidades da vida e suas expressões, e estando restritos somente aqueles que podiam dispor em liberdade dos seus movimentos e atividades. São as atividades: a). da vida de deleite dos prazeres do corpo na qual o belo é consumido naquilo que é dado; b). A vida política dedicada aos assuntos da pólis; c). Por fim, a vida do filósofo dedicada à investigação e à contemplação daquilo que é eterno. No entanto, para Arendt, é somente na vida dedicada à pólis que se constitui o fulcro do conceito de "vida activa", marcada pela liberdade e livre forma de organização política. Arendt se apoia fundamentalmente na distinção entre governo despótico e política, quando estabelece que a vida do déspota é distinta da vida política em razão daquele se dedicar as coisas que são necessárias à vida, enquanto a vida política é dedicada à vida dos homens livres. Só que em Aristóteles, segundo Arendt, e a partir deste ponto ela passa à crítica ao Estagirita, não mais se identificando com sua filosofia política, na articulação interna dos diferentes modos de vida, escalona-se uma hierarquia em que o prazer tem um papel inferior, a vida política um papel intermediário, e a vida contemplativa ocupa uma posição superior. Esta última identifica-se com a skholé dos antigos, que não se restringe a ideia de lazer, mas que significa a isenção de toda atividade politica e a 
liberação de todas as preocupações e cuidados da vida cotidiana (expressões que são caras para Heidegger, como veremos. Dai porque a expressão vida activa se refere mais estritamente ao contrário da skholé, referindo-se, portanto, mais à inquietude com a qual Aristóteles identificava toda "atividade", do que propriamente ao bios politikos grego. Arendt explica que em Aristóteles, a distinção entre quietude e inquietude, entre ausência de 172 movimento físico externo e qualquer tipo de atividade, se sobrepõe à distinção entre os modos de vida político e teórico, resultando que toda atividade deve culminar na quietude da contemplação. A autora resume do seguinte modo o primado da contemplação na tradição do conceito de vita activa: "É assim que, tradicionalmente, e até o início da era moderna, a expressão vita activa jamais perdeu sua conotação negativa de "in-quietude", nec-otium, a-skholia. Como tal, permaneceu intimamente ligada à distinção grega, ainda mais fundamental, entre as coisas que são por si o que são e as coisas que devem ao homem a sua existência, entre as coisas que são physei e as coisas que são nomo. O primado da contemplação sobre a atividade baseia-se na convicção de que nenhuma obra de mãos humanas pode igualar em beleza e verdade o kosmos físico, que resolve em torno de si mesmo, em imutável eternidade, sem qualquer interferência ou assistência externa, seja humana, seja divina. Essa eternidade só se revela aos olhos mortais quando todos os movimentos e atividades humanas estão em completo repouso. Comparadas a esse estado de quietude, todas as diferenças e articulações no âmbito da vita activa desaparecem. do ponto de vista da contemplação, não importa o que perturba a necessária quietude, mas que ela seja perturbada." (CH, p. 19) Como vemos, Arendt recusa de Aristóteles a hierarquização dos modos de vida pelo bios contemplativo, ponto de partida último que passou a fundamentar na tradição o conceito de vida activa, e de onde o termo ganhou sua acepção negativa de "inquietude", de "caos" ou "movimento". Nesta perspectiva é como se fosse somente o modo de vida contemplativo o verdadeiro modo de vida a ser atingido, os demais não passando de outros tantos modos de expressão da passividade humana, e não de sua atividade. $\mathrm{O}$ ponto fundamental para Arendt consiste em extrair o conceito de vida activa de todo enxerto contemplativo, como se a "inquietude" não fosse mais algo negativo, mas a verdadeira expressão da "atividade humana". É preciso, portanto, que o aspecto ativo se sobreponha ao aspecto passivo, que a práxis adquira um valor positivo aquém da vida contemplativa, pressuposto este que para a autora não mais se encontra em Aristóteles, na medida em que este coloca a contemplação como referência última das atividades humanas.

Ora, se Aristóteles ainda permanece refém da contemplação na descrição das atividades do homem livre, Arendt nem por isso deixa de se apoiar no mesmo Aristóteles para formular sua teoria da ação, do mesmo modo que a distinção entre cidadão e escravo oferece o protótipo para a descrição da pólis nos capítulos iniciais de $\mathrm{CH}$. É o conceito de energeia que é agora visado pela autora, e é nele que a autora encontra o precedente desta valorização positiva da "atividade humana". Arendt retoma com vigor o conceito energeia de Aristóteles com o propósito de frisar na história da filosofia a irredutibilidade da práxis à produção de objetos de uso. Na explicação da autora, a energeia ou atualidade diz respeito a todas "as atividades que não visam um fim (que são ateleis) e não deixam obra alguma atrás de si (não deixam par' autas erga), atividades que esgotam todo o seu significado no próprio desempenho." (CH, p. 255). O fim (telos) buscado pela ação e pelo discurso reside na própria atividade, de modo que esta é sua própria entelécheia. A plena atualização nada realiza além de si mesma, e a realização plena da entelecheia tem por fim apenas si mesma. (Metafísica, 1050a22-35). O resultado, a obra, não se extingue em algo, mas está incrustada na própria atividade. O desempenho é a obra, é energeia." (CH, p. 255). Esta oposição entre a atividade que deixa um obra atrás de si, e esta outra que não se confundi com um produto acabado, mas que reside no próprio sujeito, aparece no parágrafo IV do livro VI da Ética a Nicômaco através da oposição entre fabricação e práxis: "nem a ação é produção nem a produção é ação. Enquanto a produção é conformada por um princípio racional que obedece a uma perícia específica, servindo-lhe, pois, de princípio verdadeiro para produzir, a disposição prática radica no elemento produtor, e não na coisa que é produzida. Agir pressupõe que cada um de nós "delibera sobre as ações que podem ser praticadas por si." 
(Ética a Nicômaco, Livro, III, 2009, p. 63). Lembremos que as ações "praticadas por si” se opõem as atividades do escravo, homens que não são de si-mesmos, mas de um outro. Os que praticam uma ação por si mesmo realizam uma obra que não é mais a obra que se confunde com um produto acabado, pois somente existe na pura atualidade, pensada, portanto, de maneira extrínseca à categoria de meios e fins. $(\mathrm{CH}$, p. 256). Na explicação de Arendt, "'a obra de um homem' não é um fim, porque os meios de realizá-la - as virtudes ou aretai - não são qualidades que podem ou não ser atualizadas, mas são, por si mesmas, 'atualidades". (CH, p. 256) Dentre as virtudes que mantém o homem na condição de atualidade pela autonomia das suas ações, nós sabemos que a phronesis é a principal virtude destacada por Aristóteles como modo de expressão da ação voluntária, pois que marcada por um processo deliberativo sobre a escolha dos meios e das finalidades da ação. No parágrafo IV do livro VI da Ética a Nicômaco, Aristóteles nos explica que deliberamos, "assim, não sobre os fins, mas sobre os meios de os atingirmos. "Propondo-se um fim, examinamos o modo como e através de que meios será possível atingi-lo." (Ética a Nicômaco, Livro III). Adiante esta distinção entre fins e meios é relativizada no processo deliberativo: "em certas ocasiões é preciso procurar pelo fim, noutras, pelo meio de se chegar lá." (Livro III, 2) É na deliberação que reside o princípio das ações realizadas pelo Homem enquanto autor das suas ações. É o que diz Aristóteles quando afirma na passagem seguinte à citação precedente, que, "Parece, por conseguinte, tal como foi dito, ser o Humano o princípio das ações e que a deliberação tem como objeto as ações susceptíveis de serem praticadas pelo próprio." (Ética a Nicômaco, Livro III). Nas ações são os seres humanos que detém os princípios condutores das ações, e nas ações deliberadas nós encontramos propriamente a expressão das ações praticadas por si.

Assim, a energeia implica um modo de atividade desprovido de todo telos (poiesis), pois o fim reside no próprio Homem. Significa que o fim reside na própria atividade, ou mais precisamente, no próprio agente. Retomaremos a questão da poeisis em seguida, quando discutirmos a relação entre Arendt e Heidegger, pois que ambos se valem de Aristóteles. Para a práxis, o fundamental na leitura de Arendt é que ela pressupõe um conjunto de relações já estabelecidas e de trocas verbais como sua condição de possibilidade, e um modo de relação marcado por uma ação individualizante: a práxis pressupõe uma subjetivação que se dá no horizonte de igualdade dos seres humanos. Essa subjetivação se traduz em um processo onde acontece a revelação do "agente" pela ação e o discurso. É a ação e o discurso que constituem o modo através do qual os seres humanos podem exprimir sua distinção. Portanto, que temos uma relação entre as ações praticadas e a identidade dos indivíduos, o agente dos atos. Arendt reapropria de Aristóteles a ideia de que a ação e o discurso dizem respeito aos seres humanos, radicando nestes os seus princípios condutores. De modo que é na Humanidade, e não na espécie humana que se encontra expresso o fato da distinção dos homens uns com os outros, e não simplesmente o desejo de comunicar algo. Nos seres humanos as ações expressam suas atualidades distintivas, diferente da alteridade que mantém para com as coisas existentes, e da distinção em relação às coisas vivas. São ações que tipificam os indivíduos, convertendo-os em seres únicos. Esta unicidade "se manifesta" pela "aparência" que os seres humanos revelam uns aos outros não como objetos físicos, mas como seres singulares. Trata-se, com efeito, explica Arendt, de um aparecimento que não se confundi com a existência corpórea, e que é estimulado pela presença dos outros, assim como do "impulso" com o qual os seres humanos respondem com uma iniciativa própria. Esta associação entre a revelação do agente e sua inserção em um contexto constituído por uma cadeia de ações estabelecidas ou a serem estabelecidas, é o que define a ação humana para Arendt. Na sua acepção nós podemos identificar um laço entre "autenticidade" e "vida público-comunitária", ou ainda, entre a história de um indivíduo através da narrativa das suas ações e palavras, e a narrativa da história de um povo, de uma sociedade histórica.

Além de Aristóteles, que é uma influência direta sobre Arendt, em consonância teórica com Heidegger, como veremos, este conceito de ação fundado na expressão do agente para um Outro pode ainda ser tomado em conta pela referência à filosofia da ação de Hegel. Em Hegel, explica Charles Taylor, nós encontramos um ponto de vista qualitativo da 
ação que se opõe ao ponto de vista causal, da mesma forma que em Arendt as ações se opõem às causas ou motivos que lhes são subjacentes justamente por possuírem uma qualidade expressiva por meio da qual os agentes se mostram. Para Hegel a ação humana possui duas dimensões, uma efetiva, através da qual é visado um fim; e outra expressiva, para a qual o agente se põe em relação à comunidade, não sendo em nada uma atividade individual. Estas atividades expressivas envolvem, desde Herder e o Romantismo Alemão, atividades corporais, o uso de signos, gestos, palavras e textos. Já para Hegel, a expressão da ação no espaço público significa dar visibilidade a um sentimento ou propósito, que é veículo de partilha de um sentimento de comunidade. Fazem uso de um espaço público que lhes confere sentido, de modo que as ações são partilhadas com os outros e com as coisas que se põem para nós. Estas duas dimensões da ação, uma efetiva e outra expressiva, fundam a possiblidade de uma comunidade (Taylor, 1983, p. 37-38). Para este ponto de vista qualitativo da ação, a questão vai consistir em mostrar que a ação irrefletida pode tornar-se consciente dos seus atos e de formular certos fins, de modo que os degraus de consciência das nossas ações são passíveis de serem finalizados pela transformação da nossa atividade. Portanto, a diferença da ação para a não-ação reside no fato que de que a ação é dirigida, e que a direção em que é tomada a situa com uma característica qualitativa diferente.

Ora, se interpretamos corretamente Arendt em relação à Aristóteles, a ênfase é concedida não nos fins, e sim na deliberação sobre os meios. Os fins são secundários em relação aos meios através dos quais uma ação é deliberada, e finalmente decidida. A referência a Aristóteles é fundamental para Arendt pensar a ação por meio do conceito de energeia, pois delimita uma atividade em que meios e fins não são separados nos assuntos que dizem respeito às contingências humanas. Ao mesmo tempo, a ênfase concedida à revelação do agente através da ação e do discurso partilha da ênfase concedida por Hegel ao expressivismo do agente diante da sua comunidade política, pois ambos há uma relação entre ação e revelação do agente, entre ação e visibilidade, em que pese a recusa da autora dos fins perseguidos de maneira consciente como seu critério definidor, como em Hegel, já que Arendt enfatiza não a consciência dos fins a serem atingidos, mas sim o processo deliberativo das opiniões. Sob esta ótica, Hegel estaria ainda preso na tradição do bios teoretikos, e nós veremos a seguir de que modo esta leitura crítica de Hegel se operou com Marx e "as filosofias da ação" dos jovens hegelianos quando discutirmos o conceito de "inversão".

Continuando com Arendt, cumpre observar que a referência à ação por si só não dá conta das articulações que compõe o conceito de vida activa, porque, além da ação, nós temos a fabricação de objetos úteis e o trabalho através do qual o homem reproduz sua existência. Com o objetivo de explicarmos todas as articulações conceituais que estão envoltas na definição do homem como um ser ativo e condicionado, nós focaremos nossa atenção, em primeiro lugar, na relação de Arendt com Heidegger em torno do conceito de mundo ambiente, para em seguida, discutirmos a relação de Arendt com Marx em torno do conceito de vida activa.

\section{O DiÁlogo IMPLÍCITO COM HEIDEGGER}

Ao mesmo que Arendt mobiliza o conceito de energeia em Aristóteles, uma reapropriação das categorias de Ser e Tempo de Heidegger se opera em $\mathrm{CH}$. Nossa tese é: a influência de Heidegger sobre Arendt se refere muito mais ao discernimento do conceito de "condição" como ser-no-mundo, do que à primazia aristotélica da práxis sobre a poiesis, já que Arendt e Heidegger divergem quando ao modo de apreender a práxis. A seguinte passagem atesta este ponto. "A vita activa, a vida humana a medida em que está ativamente empenhada em fazer algo, está sempre enraizada em um mundo de homens ou de coisas feitas pelos homens, um mundo que ela jamais abandona ou chega a transcender completamente. As coisas e os homens constituem o ambiente de cada uma das atividades humanas, que não teriam sentido sem tal localização; e, no entanto, esse ambiente, o mundo no qual nascemos, não existiria sem a atividade humana que o produziu, como no caso de 
coisas fabricadas; que dela cuida, como o caso das terras de cultivo; ou que o estabeleceu por meio da organização, como no caso do corpo político." ( $\mathrm{CH}$, p. 27). Constata-se que Arendt concede uma primazia ao conceito de vida ativa: são as atividades humanas, a produção de objetos de uso, o trabalho e a práxis política que são fundamentais. Do mesmo modo que Aristóteles concede uma primazia da práxis sobre a poiesis, Arendt sobrepõe o conceito de "atividade humana" aos condicionamentos nos quais se encontra enquadrada. Isto é, o ser humano é um ser ativo: são as atividades que lhes definem enquanto tal, mesmo que os seres humanos sejam condicionados pelo mundo ambiente no qual eles vivem. Portanto, nenhum condicionamento esgota a capacidade de atividade dos sujeitos $(\mathrm{CH}$, p.12). Veremos que esse primado da "atividade humana" sobre os condicionamentos também é fundamental para Marx. Por hora, uma observação fundamental a ser feita, explicando a citação acima, é que, além de um ser ativo, os seres humanos são também seres condicionados ou localizados em um ambiente mundano: a vita activa enquanto vida empenhada em fazer algo se encontra localizada dentro de certos limites. Para Arendt, estes limites são o ambiente das coisas e dos homens. Um ambiente de coisas feitas pelos homens, e os homens situados no espaço estabelecido pelas coisas.

Em primeiro lugar, do lado das coisas, Arendt mobiliza essencialmente o conceito de obra (working, fabricatin gandbuilding) para dar conta do mundo no qual se desdobra a lida ativa do homem. Arendt define a obra do seguinte modo: "A verdadeira obra da fabricação (work of fabrication, Herstellung) é executada sob a orientação de um modelo segundo o qual se constrói o objeto. Esse modelo pode ser uma imagem vista pelos olhos da mente ou um esboço, na qual a imagem já passou por um ensaio de materialização por meio da obra. Em cada caso, o que orienta a obra da fabricação está fora do fabricante e precede o efetivo processo da obra (...)." (CH, p. 174-175). Este modelo é operacionalizado tendo em vista uma finalidade, qual seja, a produção de um objeto particular: a matéria extraída da natureza é convertida em um produto final, seu telos, seguindo o modelo que informa a produção do objeto. Com a forma encarnada em uma matéria talhada, a obra manufaturada passa então a dispor de uma solidez que se torna constitutiva da estabilidade do mundo, diante dos ciclos naturais, fazendo assim com que esta estabilidade se torne um modo de condicionamento dos seres humanos, uma condição para sua existência. Enfim, no interior do condicionamento dos objetos produzidos, nós temos um modo de lida ativa com os objetos mundanos ou obra produzida. Arendt, valendo-se de Heidegger, como consta a seguir, considera que é o uso o modo através do qual se dá essa lida ativa: "O uso adequado delas não causa seu desaparecimento elas dão ao artifício humano a estabilidade e a solidez sem a quais não se poderia contar com ele para abrigar a criatura mortal e instável que é o homem. ... a destruição, embora inevitável, é incidental com relação ao uso, mas inerente ao consumo." (CH, p. 169) O uso das coisas, e não o seu consumo, constitui o pressuposto através do qual um mundo comum é assegurado, pois permite o uso dos objetos sem que estes sejam devorados no metabolismo do consumo. Para a questão do consumo e sua relação com o uso, a influência já não é mais Heidegger, e sim Marx, como também veremos adiante.

Ainda sobre o caráter condicionado da vida activa no parágrafo citado, do lado dos homens, e não mais das coisas, o ambiente cotidiano ao qual se refere Arendt enquanto modo de condicionamento das atividades é o comum, a pluralidade. Em $\mathrm{CH}$, Arendt define a pluralidade como a condição da práxis política. Não há práxis sem pluralidade. Esta pluralidade possui um sentido particular: significa a igualdade e a diferença, isto é, a igualdade que partilhamos com os demais seres humanos, e a distinção específica de cada um, envolvendo assim o aspecto da universalidade partilhada com os demais seres humanos, e a diferença que é própria a cada um. Ora, se existe um laço da pluralidade com a ação, do mesmo modo que existe entre a fabricação e a produção de objetos duráveis, nem por isso nós devemos confundir a pluralidade como condição da ação com a própria ação. Se compreendemos corretamente Arendt, a pluralidade é condição para a práxis por que lhe é essencial o conceito de igualdade, sendo que a diferença, a distinção própria a cada um, o resultado da ação, que se faz numa teia de ações e numa temporalidade histórica já estabelecida. É assim que Arendt escreve que a "pluralidade é a condição da ação humana 
porque somos todos iguais, isto é, humanos, de um modo tal que ninguém jamais é igual a qualquer outro que viveu, vive ou viverá." $(\mathrm{CH},($ p. 10$)$. O primeiro enunciado é inequívoco: a pluralidade é a condição da ação porque nela se encontra expressa a igualdade entre os seres humanos, e graças ao fato desta igualdade podemos expressar nossas diferenças por meio de nossas ações. Portanto, dizer que não há ação sem pluralidade significa que a ação parte de uma igualdade comum aos diferentes sujeitos, e que, sob o fundo desta igualdade, ocorre a expressão das suas identidades na comunidade em que vivem.

Portanto, é justo salientar que em $\mathrm{CH}$ nós encontramos um destaque fundamental dado ao conceito de "condição", expressão do nosso condicionamento, da dependência dos homens enquanto seres condicionados pelas coisas que constituem o ambiente mundano. $\mathrm{E}$ que "as coisas" e os "homens" constituem dois modos de condicionamento diferenciados, mas que se articulam, pois se a ação não ocorre sem condicionamentos, é porque há uma relação entre as ações e os objetos manufaturados que a circundam. Do ponto de vista filosófico, esta discussão sobre o "ambiente mundano" que condiciona as ações humanas se remete implicitamente à Heidegger, pois é na obra Ser e Tempo que Heidegger articula a descrição da obra produzida e usada com o mundo público da existência humana. Em $A C H$ Arendt não faz nenhuma referência à Heidegger, ao contrário das recorrentes referências à Marx e à Aristóteles. No entanto, uma reapropriação das categorias da ontologia existencial é implicitamente mobilizada em $\mathrm{CH}$. Em primeiro lugar, a análise do "mundo ambiente" desenvolvida em Ser e Tempo recobre a passagem em que Arendt se refere ao "mundo ambiente" no qual se encontra localizado as atividades humanas. Por mundo ambiente Heidegger entende o mundo mais imediato que caracteriza o cotidiano do ser-aí. Trata-se do mundo mediano da existência humana no qual os seres humanos habitam uma certa espacialidade. Nesta configuração mundana, o ser-aí é dado sob o modo da preocupação com os entes que são acessíveis na lida cotidiana. Esta lida é dada na forma da preocupação, do atarefamento com os objetos que são utilizados numa atividade específica. Tal acessibilidade se constitui através do uso dos objetos disponíveis que o ser-aí manipula na familiaridade mantida com o mundo circundante. Aquilo que nós usamos constituem os entes fenomenológicos pré-temáticos. Como exemplos de entes dados na cotidianidade do nosso mundo ambiente, Heidegger menciona o trinco que usamos para abrir a porta, exemplo de um ente disponível que nós usamos no nosso comércio com o mundo.

Para Heidegger o que usamos e manipulamos na nossa familiaridade com o mundo é o instrumento, verdadeiro paradigma da manipulabilidade das coisas disponíveis ao uso. $\mathrm{Na}$ descrição fenomenológica do instrumento, Heidegger afirma que o instrumento é algo feito para, de modo que nós temos o reenvio de alguma coisa para algo. O envio provém da manualidade, do uso com a mão. Uma série de envios constitui uma multiplicidade articulada: um instrumento pertence a um outro instrumento, de modo que cada instrumento é remetido a um conjunto de instrumentos no interior dos quais eles funcionam. A relação entre utensílio e uso é pensada de maneira articulada por Heidegger no exemplo do martelo:

Dans un tel commerce d'usage, la préoccupation se soumet au 'fait pour' constitutif de chaque útil; moins la chose-marteau est fixé des yeux, mieux le marteau est empoigné pour être employé, d'autant plus original est le rapport à lui, d'autant plus il se rencontre sous son vrai visage, commece qu'il est, comme util. Taper un coup de marteau, rien de tel pour dévoiler la 'manualité' spécifique du marteau. Le genre d'être d'util dans lequel il se manifeste de lui-même nous appelons utilisabilité. C'est seulement parce que l'util a cet'être-en-soi' et ne se limite pas seulement à apparaître qu'il est maniable au sens le plus large et disponible. (HEIDEGGER, 1986, p. 105).

Já o sentido do instrumento enquanto 'feito para' reside na obra. O martelo é um gênero de instrumento destinado a produção da obra, no exemplo de Heidegger. Esta se encontra enfim disponível no comércio instalado pela preocupação, estando assim disponível para um emprego específico. O relógio produzido que funciona adequadamente é feito para fornecer a hora: a obra é feita para um emprego específico. A obra que é feita tem por razão de ser o uso que será o seu, e o conjunto de reenvios que é desvelado neste uso. $\mathrm{O}$ uso é determinado por aquilo que se encontra "sob a mão", de modo que o utilizável no 
comércio cotidiano do ser-aí é dado no espaço do mundo ambiente pela proximidade. (HEIDEGGER, 1986, p. 142). Além do uso, a obra, explica Heidegger, remete-se também a materiais. O que significa que no instrumento colocado em uso e pelo seu uso se desvela simultaneamente a natureza, colocada à luz nos seus produtos naturais. Nessa conformação da natureza aos produtos, Heidegger assinala que a obra produzida é reenviada igualmente ao sujeito que usa. Isto é, aquele que usa a obra produzida se encontra presente no nascimento da obra, em razão do fato de que com a obra produzida o destinatário que a utiliza entra na composição do produto. Como assinala Heidegger, a obra que é suscetível de ser utilizada é destinada a um mundo público.

$\mathrm{Na}$ seção 26 de Ser e Tempo esta articulação entre instrumento, obra e mundo público é elucidada em pormenor. É a clássica análise do Mitwelt em Ser e Tempo. Heidegger explica que no mundo ambiente imediato, como por exemplo, o mundo onde o artesão fabrica seus produtos, os outros se encontram presentes como aqueles para os quais a obra é destinada. Isto é, os outros a quem a obra se destina são os possíveis utilizadores; ou então os fornecedores de material para a produção dos produtos artesanais. Os outros não são, analisa Heidegger o mundo público, algo que se encontra diante dos sujeitos como coisas aí subsistentes, mas ao contrário: as coisas emergem no mundo à medida que elas são utilizadas pelos outros. Os outros em questão não são assim simplesmente aqueles que permanecem exteriores aos sujeitos, mas sim aqueles nos quais na maior parte do tempo nós não nos distinguimos. Ser com os outros designa assim um modo existencial partilhado com os outros. Assim, o mundo público cotidiano é um mundo comum: o ser que habita o mundo é um ser que partilha um mundo comum com os outros, isto é, uma coexistência (Mitdasein).

Les autres ne se rencontrent pas à partir du moment où l'on fait la différence préalable entre son propre sujet d'abord là-devant et les autres sujets qui se rencontrent eux aussi, ni en dirigeant un tout premier regard sur soi-même pour commencer par y fixer le terme premier d'une différenciation. Ils se rencontrent à partir du monde dans lequel séjourne essentiellement le Dasein préoccupé et discernant. À l'encontre des 'éclaircissement' si prompts à s'insinuer par lesquels on s'imagine ce que serait en théorie l'être là-devant des autres, il faut s'en tenir strictement à l'état de fait qui a été montré phénoménalement, celui de leur rencontre au beau milieu du monde ambiant. Ce genre immédiat et élémentaire de rencontre du Dasein qui m'est propre, il n'est d'emblée 'trouvable' de lui-même que là où je détourne les yeux des 'vécus' et du 'centre d'actes' - à moins que je ne les 'voie' pas du tout encore. Le Dasein 'se' trouve 'lui-même' d'emblée dans ce qu'il exerce, utilise, attend, empêche - dans l'utilisable dont d'emblée il se préoccupe au sein du monde ambiant. (Heidegger, 1986, p. 161).

Na mesma secção 26, Heidegger expõe o problema do Dasein e da coexistência com os outros na sua articulação com o utilizável no interior do mundo do seguinte modo:

Le Dasein s'entend d'abord et le plus souvent à partir de son monde et la coexistence des autres se rencontre de multiple façon à partir de l'utilisable intérieur au monde. Mais même si les autres sont en quelque sorte thématisés dans leur Dasein, ils ne se rencontrent pas à titre de choses-personnes là-devant, au contraire nous prenons contact avec eux 'au travail', c'est-à-dire de prime abord dans leur être-au-monde. Même quand nous voyons l'autre rester simplement là "à ne rien faire" est un mode d'être existential: celui qui s'attarde, flânant auprès de tout et de rien, en l'absence de toute préoccupation et de toute discernation. L'autre se rencontre en sa coexistence dans le monde. (HEIDEGGER, 1986, p. 162).

Resumindo, o utilizável no interior do mundo torna possível o encontro com o outro. Com efeito, os outros não se encontram como pessoas dispostas diante de um sujeito, mas em contato, como coexistência no mundo ambiente. Em resumo, fica patente que Heidegger fundamenta o ser-com no espaço estabelecido pela obra. O mundo do ser-aí cotidiano é o mundo da poiesis aristotélica, pois se encontra referenciado no mundo dos objetos produzidos. (Taminiaux, 1991, p. 128) Neste mundo o ser-aí nunca está voltado para a sua propriedade, aquilo que lhe é autenticamente mais próprio, mas encontra-se preocupado com as finalidades da vida cotidiana, em atingir objetivos específicos. O que significa que no cotidiano a preocupação do ser-aí é de tal sorte que ele nunca pode ocupar-se consigo. 
Portanto, o mundo ambiente é um lugar de impropriedade, de decadência, pois a imersão nas coisas faz com que o ser-aí se perca no domínio dos hábitos que constituem nosso cotidiano.

Essa referência filosófica é decisiva para $A$ Condição Humana: Arendt estabelece uma correspondência entre a fabricação de objetos e a constituição de um mundo ambiente.

178 Do mesmo que Heidegger, é o uso o modo através do qual se estabelece uma lida ativa com o mundo, e é através do instrumento que esta lida se processa. Tanto quanto para Heidegger, Arendt considera que não é na produção de objetos duráveis e nem tampouco no uso destes objetos que reside a autenticidade do sujeito, mas sim na ação, na práxis. É somente nesta que nós encontramos um agente. Mas para tratar da práxis, nós devemos não mais levar em conta a influência de Heidegger, pois que Arendt concede um enfoque na práxis valorizando o conceito de pluralidade que nós não encontramos em Heidegger. Para o autor de Ser e Tempo, é na resolução em marcha onde se ancora o agir, e esta resolução se ancora em uma situação carregada de possibilidades. É enquanto resolução que o ser-aí age, desde que por esse termo nós assinalemos que Heidegger compreende que o agir envolve uma atividade global que engajando até a passividade da resistência, e ocorrendo dentro do quadro das possibilidades existenciais factivas. (Heidegger, 1986, p.359). Já Arendt, como vimos, se ancora diretamente no conceito de "energeia" em Aristóteles encarregado de dar conta da sobreposição do agir sobre o fabricar, e pela descrição da política como um modo de vida marcado pela ação e pelo discurso. Portanto, que o agir comporta uma dimensão deliberativa e intersubjetiva. E a este respeito, nós podemos nos perguntar se não se arma uma contraposição entre os dois autores na valorização do agir prático em contraposição ao mundo dos objetos manipuláveis, o mundo cotidiano do ser-aí na apropriação que Arendt e Heidegger fazem de Aristóteles ao descrever o mundo da "obra". Jacques Taminiaux em ensaio dedicado à apreensão das categorias poiesis-praxis da Ética à Nicômaco em Ser e Tempo, cuja referência foi já evocada, argumenta que nós podemos, em última instância, ver em Arendt um primado mais radical da práxis em relação com o bios teoretikos comparado à Heidegger. Taminiaux analisa Ser e Tempo colocando em correlação a dualidade entre autenticidade (Eigentichkeit) - inautenticidade (Uneigentlichkeit) com par de conceitos praxis-poiesis do livro VI da Ética a Nicômaco, objeto de discussão pelo autor de Ser e Tempo no curso de 1922 Interpretações fenomenológicas de Aristóteles (nota), e capital para a distinção de Arendt de $A$ Condição Humana já mencionada entre práxis e poiesis. A poeisis se tona o modelo da relação do homem ao mundo cotidiano, e, por extensão, ao mundo da Vorhandenheit, uma vez que as coisas disponíveis ao uso, à manualidade, estão disponíveis para um uso eventual; já quanto a práxis, nós encontramos uma diferença profunda no modo de apropriação de Arendt e Heidegger de Aristóteles, onde Heidegger é criticado por invalidar o relação da práxis com a pluralidade do processo deliberativo e as opiniões, reversível e frágil, fato enfatizado por Arendt, que é mais próxima de Aristóteles ao mostrar a relação do agir com o processo deliberativo. Na Ética a Nicômaco a descrição das ações voluntárias foca esta intricação do agir com as opiniões que examinam os meios para atingir-se fins através do processo deliberativo: "Nós deliberamos sobre aquelas coisas que nos dizem respeito e que dependem de nós, a saber sobre as ações que podem ser praticadas por nós. ... Antes, propondo-se um fim, examinamos o modo como e através de que meios será possível atingi-lo." (Ética a Nicômaco, Livro III, p. 62-63). Já na ontologia fundamental, no comentário de Arendt sobre Heidegger,

"The essential character of the Self is its absolute Self-ness, its radical separation from all its fellows. Heidegger introduced the anticipation of death as an existential in order to define this essential character, for it is in death that man realizes the absolute principium individuationis. Death alone removes him from connection with those who are his fellows and who as "They" constantly prevent his being-a-Self. Though death may be the end of Dasein, it is at the same time the guarantor that all that matters ultimately is myself. In experiencing death as nothingness as such, I have the opportunity to devote myself exclusively to being-a-Self and, in the mode of axiomatic guilt, to free myself once and for all from the world that entangles me. What emerges from this absolute isolation is a concept of the Self as the total opposite of man." (Arendt, 2005, p.181). 
$\mathrm{Na}$ ontologia fundamental a transcendência é dominada pela resistência da autenticidade à inautenticidade do Impessoal, de modo que a individuação do si-mesmo é separada dos Outros com os quais os sujeitos entram em contato. Ou em termos platônicos, pela resistência do Um ao Múltiplo, isto é, do poder-ser-si-mesmo que abre o ser-aí ao agir na sua solidão individualizante em oposição ao falatório e a decadência dos hábitos da vida cotidiana. Retomando o conceito de resolução como cerne do registro da práxis em Heidegger, tratar-se-ia de confrontar a existência na sua individualidade pura como sujeito com o ser-com os outros, no qual o ser no mundo cotidiano é considerado como inautêntico, (Taminiaux, 1991, p. 131) e não como lugar de revelação dos sujeitos. No âmbito do discurso, a Gewissen em Heidegger como lugar da fala interpelante do sujeito ao seu poderser-si-mesmo, nós temos simplesmente o diálogo solitário da alma consigo mesmo que o incita a agir. (Taminiaux, idem; Heidegger, 1986, p. 324).

Nosso acréscimo a esta leitura de Arendt de J. Taminiaux, (Taminiaux, 1986) assim como à de Dana Villa, (Vila, 1996) é que se em $\mathrm{CH}$ Heidegger é ultrapassado no que concerne à valorização do agir em comum, ao aliar a ação à pluralidade de opiniões através das quais os agentes revelam suas identidades em comum, de modo que o autor de Ser e Tempo permaneceu ainda no horizonte do bios teoretikos, não é menos verdade que esta valorização da práxis como "agir em comum" sobre as condições de existência encontra em Marx sua expressão filosófica, autor em quem Arendt reconhece um ponto marcante na história do conceito de vida activa em $\mathrm{CH}$, e que, ademais, ocupa um lugar de destaque em $\mathrm{CH}$ e em outros textos de Arendt. Partirei do postulado de que é possível colocar em correspondência Arendt com Marx não somente naquilo que concerne a valorização ou primado da práxis em comum sobre a condições de existência ou o objeto, mas também o quanto a distinção entre "obra" e "trabalho" em $C H$ encontra-se em $O$ Capital por meio da oposição entre valor de uso e valor de troca. Ademais, em que pese a influência de Heidegger e Aristóteles sobre Arendt em $\mathrm{CH}$, além dos reparos críticos feitos por Arendt a estes autores no que concerne ao primado do agir, ela permanece insuficiente para apreendermos a outra atividade que constitui a vida activa além da ação e da obra, que é o trabalho.

\section{O DeSdobRamento CRítico COM MARX (I) (PARTE 2)}

Vimos que em Arendt nós temos o primado da atividade sobre as condições. As condições enquanto determinações ou limites da existência funcionam para um ser que é ativo. A vida do corpo, a objetividade do mundo e a pluralidade humana funcionam como correlativos para as atividades do trabalho, da fabricação e da ação. Ora, o primado da atividade sobre o objeto é um pressuposto também fundamental para Marx, cujo conteúdo da práxis na sua relação com o conceito de condição nós devemos analisar agora. Vale ser acrescentado que a discussão de Arendt com Marx é fundamental, pois envolve tanto o conjunto das atividades que compõe o conceito de vida activa, e não somente o trabalho, quanto a problemática filosófica concernente a inversão do predomínio da vida activa sobre a vida contemplativa, tema fundamental da obra $\mathrm{CH}$. Se Arendt mobiliza explicitamente Aristóteles e implicitamente Heidegger, como vimos até agora, seu propósito em $A$ Condição Humana é criticar Marx. Com efeito, a influência de Heidegger e Aristóteles é decisiva na análise do conceito de obra e de práxis. Fundamenta o contraponto teórico à Marx na análise do trabalho e a própria apreensão negativa de Arendt do trabalho. Todavia, argumentarei contra a leitura de Arendt de Marx, mas em parte a favor dos conceitos de Arendt, que nós encontramos em Marx um conceito de vida activa que contempla a inversão da contemplação pela práxis, e, em segundo lugar, que nós encontramos em Marx a distinção entre trabalho e obra. Estes dois momentos recobrem as duas partes em que Marx aparece em $\mathrm{CH}$ : a primeira diz respeito a prolongação do conceito de vida activa até Marx no capítulo sobre o conceito de vida activa, e a segunda, sobre o conceito de trabalho em Marx na análise da atividade do trabalho. (CH, p. 110-130.)

Primeiro vejamos a leitura de Arendt do conceito de trabalho em Marx, questão cujo 
desenvolvimento não será exaustivo neste texto, pois nosso interesse é muito mais entender de que modo o primado da práxis em Marx aparece como um problema filosófico na análise de Arendt do conceito de vida activa em $\mathrm{CH}$. Sobre a atividade do trabalho, cuja condição é a vida do corpo, diz Arendt que ao "contrário da atividade da obra [working], que termina quando o objeto está acabado, pronto para ser acrescentado ao mundo comum de coisas, a atividade do trabalho [laboring] move-se sempre no mesmo círculo prescrito pelo processo biológico do organismo vivo, e o fim de suas 'fadigas e penas' só advém com a morte desse organismo." ( $\mathrm{CH}$, p. 33). Para Arendt, é em Marx que nós encontramos teorizada esta formulação: "Ao definir o trabalho como 'o metabolismo do homem com a natureza', em cujo processo 'o material da natureza [é] adaptado, por uma mudança de forma, às necessidades do homem', de sorte que o 'o trabalho se incorpora a seu sujeito', Marx deixou claro que estava 'falando fisiologicamente', e que o trabalho e o consumo são apenas dois estágios do ciclo sempre recorrente da vida biológica." (CH, p. 121) Com Aristóteles e Heidegger, nós apreendemos, respectivamente, a origem das categorias da práxis e da obra em Arendt. Já com Marx, Arendt expõe o conceito de trabalho, e o circunscreve entre dois polos: trabalho e consumo, dois estágios do ciclo da vida biológica: "Tudo o que o trabalho produz destina-se a alimentar quase imediatamente o processo da vida humana, e esse consumo, regenerando o processo vital, produz - ou antes, reproduz - nova 'força de trabalho' de que o corpo necessita para seu posterior sustento." (CH, p. 122). Ao mesmo tempo que define o trabalho como metabolismo com a natureza, pois envolve uma apropriação da natureza pelo corpo que trabalha, Arendt analisa que Marx atribui ao trabalho propriedades que somente pertencem a obra. Nas palavras de Arendt: "A era moderna em geral e Karl Marx em particular, fascinados, por assim dizer, pela atual produtividade sem precedentes da humanidade ocidental, tendiam quase irresistivelmente a considerar todo trabalho como obra e a falar do animal laborans em termos muito mais adequados ao homo faber, como a esperar que faltasse apenas um passo para eliminar totalmente o trabalho e a necessidade." (CH, p. 107). Esta crítica não impede Arendt de evocar passagens importantes de Marx nas quais nós encontramos a definição do trabalho produtor de valor de uso por meios dos instrumentos de trabalho.

Retomemos agora Marx, e vejamos como a proximidade entre os dois autores é muito maior do que a distância crítica assinalada por Arendt. Arendt apreende o trabalho como metabolismo com a natureza em Marx, considerando que do ponto de vista desta definição Marx entra em contradição ao definir o trabalho igualmente como uma atividade produtora de valor de uso. Ora, esta definição somente apreende o trabalho como uma atividade independente de toda forma de sociedade. Como versa o livro I do Capital de Marx: "Le procès de travail, tel que nous l'avons exposé dans ses moments simples et abstraits, est une activité qui a pour fin la fabrication de valeurs d'usage, il est l'appropriation de l'élément naturel en function des besoins humains, il est la condition générale du métabolisme entre l'homme et la nature, la condition naturelle éternelle de la vie des hommes; il est donc independent de telle ou telle forme qu'elle revêt, mais au contraire également commun à toutes ses formes sociales." (Marx, 1993, p. 207). Com efeito, é importante observar que Marx apreende o trabalho como um processo, envolvendo assim uma multiplicidade de fatores: cada fator de produção se torna uma condição de possibilidade para a realização do processo inteiro. Em segundo lugar, na sua forma simples, o processo de trabalho é produção de valor de uso $e$ metabolismo com a natureza. $\mathrm{O}$ conjunto dos objetos produzidos constitui a riqueza da sociedade cuja finalidade é atender as necessidades humanas: uma cadeira produzida é usada com a finalidade de atender à necessidade humana de sentar. Enfim, esta definição pressupõe uma explicitação geral do trabalho comum a todas as formas sociais, não dando conta da especificidade do trabalho dentro da produção capitalista, como trabalho produtor de mercadorias. Neste último sentido o trabalho já não é mais uma atividade teleológica através da qual o homem reproduz a vida através da transformação da matéria com a utilização de certos meios e visando certas finalidades, mas sim como um processo social de produção historicamente especifico. Portanto, o tempo cíclico da natureza com o qual o homem entra em metabolismo, é substituído pelo tempo social da produção - como a jornada de trabalho - necessário para a 
constituição do valor de troca das mercadorias. Na acepção de trabalho produtor de mercadorias, a multiplicidade qualitativa dos trabalhos úteis é substituída pela quantidade de trabalho empregada na produção.

Esta duplicidade do trabalho como produtor de valor de uso e produtor de valor de troca é fundamental para Marx, e se não temos ela em conta, perdemos de vista a especificidade do trabalho na sociedade capitalista (POSTONE, 2014). Irredutível à produção de valor de uso, o trabalho produtor de mercadorias não se define mais pelo que produzir e o modo de se produzir, mas pela duração da produção. Ancorado na medida do tempo, o valor das mercadorias se define pelo trabalho abstrato, pelo quantum de trabalho necessário à produção de mercadorias. A quantidade de trabalho engajada é medida pela duração do tempo envolvido, e o tempo de trabalho, por sua vez, possui sua medida determinada em horas, jornadas de trabalho, etc. Este trabalho envolvido na produção, diz Marx, é um trabalho abstrato, desgaste de trabalho no processo produtivo. Não se trata de maneira alguma de um trabalho de reprodução biológica dos seres humanos, mas de um trabalho médio, onde é requerido um tempo de trabalho médio necessário à produção de valores de uso. "Le temps de travail socialement nécessaire est le temps de travail qu'il faut pour faire apparaitre une valeur d'usage quelquonque dans les conditions de production normales d'une société donné et avec le degré social moyen d'habilité et d'intensité du travail." (Marx, 1993, p. 44). Dois elementos sociais entram na determinação do trabalho abstrato, como o degrau médio de habilidade e a intensidade do trabalho, outro fator temporal fundamental, fazendo com que os produtos disponíveis ao uso sejam o resultado das condições de produção de uma sociedade.

Nos termos de Marx, a definição do trabalho como metabolismo com a natureza define o trabalho de maneira a-histórica, e nesta definição está envolvida a imaginação da obra a ser produzida, a matéria, os instrumentos e os produtos do trabalho, isto é, a lógica produtiva através da qual Arendt apreende o homo faber. Mas o ponto fundamental para Marx é a especificidade do trabalho produtor de mercadorias em que o tempo de trabalho é requisitado para a produção de mercadorias. Neste ponto, a força produtiva do trabalho é determinada por múltiplas circunstâncias, como o grau médio de habilidade dos trabalhadores, o nível de desenvolvimento da ciência e de suas possibilidades de aplicação pela tecnologia, pela combinação social do processo de produção, pela amplidão e a capacidade operativa dos meios de produção e pelos dados naturais. (Marx, Le Capitale, 1993, p. 45) Portanto, Marx define o trabalho tanto como obra, em relação ao qual está associado os valores de uso ou de consumo, e cuja soma constitui o conteúdo material da riqueza de qualquer sociedade, tanto quanto como trabalho abstrato produtor de mercadorias. Esta duplicidade ultrapassa a definição de Arendt segundo a qual o trabalho em Marx se define a partir da figura do animal laborans, simplesmente voltado a reprodução biológica da vida a partir da lógica da produção e do consumo. O que significa que a duplicidade entre trabalho e obra se apresenta em Marx não como uma contradição teórica, terminológica, como assinala Arendt quando diz que Marx atribui ao trabalho qualidades que pertencem somente à obra. Trata-se de uma distinção real que recobre a diferença entre o trabalho produtor de valor de uso e do trabalho produtor de valor de troca. Vale ainda ser acrescentado que Arendt interpreta a produtividade do trabalho em Marx sem apreender a composição global do modo de produção capitalista esmiuçada por Marx. Encara a produtividade do trabalho na "força de trabalho humana", cujo vigor é capaz de produzir um excedente $(\mathrm{CH}$, p. 108) mais do que necessário à sua reprodução biológica. Para Arendt não é o trabalho abstrato, mas o excedente da "força de trabalho humana" que explica a produtividade do trabalho (Arbeitskraft), de onde a associação desta produtividade com a procriação, a reprodução biológica da espécie.

\section{Práxis e Condição (II)}

Agora analisemos a categoria da práxis. Do lado da distinção entre trabalho e obra, nós encontramos uma correspondência entre os dois autores, com a ressalva fundamental de 
que a teoria de Arendt do trabalho não recobre a de Marx, mas somente o trabalho definido de maneira a-histórica, o que Marx chama de trabalho produtor de riqueza. Para a categoria da práxis, a outra atividade que constitui a vida activa, também é possível colocarmos em correspondência os dois autores. Para os nossos propósitos, bastará a referência às Teses sobre Feuerbach (doravante TF) e A Ideologia Alemã, obras nas quais Marx discute os 182 conceitos de "atividade" e de "condição", assim como o conceito fundamental de inversão (Umkehrung), ambos conceitos comuns a Arendt e Marx.

Analisemos primeiro o conceito de inversão, pois é ele que orienta a determinação da sobreposição da vida activa ao bios theoretikos, tanto em Arendt quanto em Marx. No primeiro capítulo de $\mathrm{CH}$ Arendt explica a questão do seguinte modo: "Minha discussão é simplesmente que o enorme peso da contemplação na tradição tinha indistinguido as distinções e articulações dentro da vita activa ela mesma e que, a despeito das aparências, esta condição não tinha sido modificada essencialmente pelo moderna quebra da tradição ela mesma e que, a despeito das aparências, esta condição nao tinha sido modificada essencialmente pela moderna quebra com a tradição e a eventual inversão da ordem hierárquica em Marx e Nietzsche." (CH, p. 21) Naturalmente, deixarei de lado a referência a Nietzsche com o propósito de focar atenção somente em Marx. Por certo, Arendt segue Heidegger nesta avaliação de Marx, e o ponto de acordo consiste em interpretar a relação de Marx com a Metafísica na forma da inversão, como nota-se pela leitura da seguinte passagem de Heidegger: "Avec le retournement de la métaphysique, déjà accompli avec Karl Marx, c'est la plus extreme possibilité de la philosophie qui se trouve atteinte. La philosophie est entrée dans son stade terminal. Toute tentative de pensée philosophique ne peut plus aboutira aujourd'hui qu'à um jeu varié de renaissances épigonales." (Heidegger, 1986, p. 177) Interpretar a relação de Marx com a Metafísica pelo conceito de inversão é uma pista de investigação precisa que encontra guarida nos textos de Marx. Seguindo Heidegger, Arendt apreende a relação de Marx com a Metafísica na passagem citada através do conceito de inversão, apreendida no interior da oposição entre contemplação $e$ atividade. Esta apreensão encontra guarida nos textos de Marx, e a $4^{\text {a }} T F$ é elucidativa a este respeito. Nas $T F$ Marx está justamente voltado, através da inversão da posição de Feuerbach e dos materialismos precedentes, a sustentar a tese sobre o "lado ativo" (tatig) dos seres humanos, de modo que o conceito de atividade é fundamental na apreensão da inversão entre contemplação e atividade. Esta inversão (Umkehrung) do mundo ou sua colocação de cabeça-pra-baixo encontra sua origem na temática da duplicação - Verdoplung, notavelmente discutida na $4^{\mathrm{a}} \mathrm{TF}$ :

\begin{abstract}
"Feuerbach parte do fato da autoalienação religiosa, do desdobramento do mundo em mundo religioso e mundo profano. Seu trabalho consiste em resolver o mundo religioso em seu fundamento mundano. Mas que o fundamento mundano se desloque dele mesmo e se fixe em um reino autônomo nas nuvens só pode se explicar pela auto-separação e a autocontradição deste fundamento mundano. Aquele religioso deve ser pois nele-mesmo compreendido na sua contradição que o revoluciona praticamente. De tal maneira que uma vez, por exemplo, que a família terrestre foi descoberta como o segredo da família celeste, é doravante a primeira ela-mesma que nós devemos destruir teoricamente e praticamente." (TS, p. 21).
\end{abstract}

O procedimento da duplicação consiste em produzir cesuras que traduzem a incapacidade de compreender-se a estrutura do real e as relações internas que lhes são subjacentes, ao ocultá-las através de mistificações. Marx retoma de Feuerbach a distinção entre Céu e Terra, com o propósito de demonstrar que é equívoco aquilo que as une, isto é, que nós não concluímos do Céu à Terra, mas da Terra ao Céu. Já nas Teses Provisórias sobre a Reforma da Filosofia de Feuerbach, o conceito de "inversão" aparece do seguinte modo: "O método da crítica reformadora da filosofia especulativa em geral não se distingue do método já empregado em filosofia da religião. Nós temos que fazer do predicado (o atributo) do sujeito, e deste sujeito o objeto e o princípio, nós temos que inverter a filosofia especulativa, para ter a verdade desvelada, a verdade pura e nua." (FEUERBACH, apud LABICA, p. 47-48). Marx interioriza o esquema da inversão utilizando-o recorrentemente. Nas TF essa recorrência é mobilizada na estrutura dual, cindida, que constitui não somente a 
$4^{\mathrm{a}}$ tese, mas quase todas as teses.

Mundo

Tese 2. Pensamento-prática;

Tese 3: Circunstância-educação;

Tese 4: Mundo religioso-Mundo profano;

Tese 6: Essência religiosa-essência humana;

Tese 7: Indivíduo-forma social.

Esta estrutura dual tem uma relevância para a compreensão dos conceitos da tese 1, que é aquela que nos concerne mais diretamente com o conceito de "atividade", e sabemos que a referência a Feuerbach é crucial para a compreensão da posição de Marx. Primeiro citemos a Tese 1, para verificarmos em que medida esta operação de inversão tem um papel fundamental na formulação da posição de Marx sobre o conceito de "vida activa". Diz Marx que

O defeito principal, até aqui, de todos os materialismos, (inclusive o de Feuerbach) é que o objeto, a realidade efetiva, a sensibilidade, é tomada sob a forma de objeto de intuição; mas não como atividade sensivelmente humana, como prática, não de maneira subjetiva. É por isso que o lado ativo foi desenvolvido de maneira abstrata, em oposição ao materialismo, pelo Idealismo - que naturalmente não conhece a atividade real efetiva, sensível, como tal. Feuerbach quer os objetos sensíveis - realmente distintos dos objetos de pensamento: mas ele não toma a atividade humana ela mesma como atividade objetiva. É por isso que ele considera, na Essência do Cristianismo, que a atitude teórica é a única realmente humana, sendo que a prática é tomada e fixada somente na sua manifestação sordidamente judia. É por isso que ele não compreende a significação da atividade 'revolucionária', a atividade 'prática-crítica'. (TS, p. 19-20)

A inversão que Marx opera entre o materialismo e o Idealismo é notória na primeira tese, e ela cumpre um papel justamente na ênfase concedida ao "lado ativo" desenvolvido pelo Idealismo, em oposição à ênfase concedida pelo materialismo, inclusive o de Feuerbach, no objeto de intuição. Este "lado ativo" desenvolvido pelo Idealismo se refere ao conceito de "atividade" (TF, p. 19-20) (Tatigkeit), aprofundado através da seguintes conotações e distinções:

A primeira equação aponta para "atividade sensivelmente humana $=$ prática $=$ subjetiva, oposta ao objeto $=$ intuição $=$ realidade efetiva $=$ sensibilidade. $\mathrm{O}$ primeiro aspecto se opõe ao materialismo que parte do objeto de intuição

Uma segunda equação estabelece o equívoco de Feuerbach e dos Idealistas quando Marx estabelece a equação entre "atividade humana" e "atividade objetiva" (gegenstandliche), fórmula não mais redutível ao conceito de "atividade" dos Idealistas. Feuerbach identifica objetos sensíveis que resistem a abstração, mas ele não é capaz de dar conta da atividade sensível que lhes é subjacente. A "atividade sensível" permite pensar o conceito de "atividade" além do aspecto abstrato desenvolvido pelo Idealismo. (TS, p. 32) Feuerbach é, portanto, incapaz de conceder uma primazia à prática, considerada como a única verdadeiramente humana; só vê nela os aspectos sórdidos, assimilando as especulações do seu tempo concernente à identificação de prática com o egoísmo e o utilitarismo dos judeus das classes altas. (idem).

Por fim, o último aspecto diz respeito a delimitação do conceito de "atividade" por Marx a partir de "atividade revolucionária, prática crítica." Como observa Labica, de quem retomo os comentários das $\mathrm{TF}$, estes termos assinalam um ponto de não-retorno de Marx contra à filosofia. Revolucionário, ou praticamente crítico, opera uma modificação nos conceitos da Tese 1, que contrapõem a atividade ao objeto, à realidade, à sensibilidade. $\mathrm{A}$ atividade no sentido de Marx rearticula o sensível, (sinnliche Tatigkeit), o real e o objetivo. Assim fazendo, Marx propõe uma demarcação mais profunda que o Idealismo concernente ao "lado ativo" que inverte o materialismo. Marx faz referência ao seu homólogo "prática", "práxis": a atividade para se tornar prática deve se incorporar no sensivelmente humano, no subjetivo. A "atividade", o "lado ativo" cede lugar a "atividade pratica sensivelmente humana" na Tese 5, e na Tese 8 e 9, a "atividade prática." Filosofia da práxis comporta nesse 
sentido uma irredutibilidade relativa ao Idealismo: o conceito de prática comporta uma dimensão social, como frisa a tese 8, onde Marx afirma que "Toda a vida social é essencialmente prática", de modo que o aspecto subjetivo da atividade indicado por Marx na Tese 1, é ao mesmo tempo social, assim como o ser humano na sua essência é um ser social. (idem, p. 96). Marx assinala que o Idealismo leva vantagem sobre o materialismo, pois ele introduz diretamente o âmbito subjetivo, do sujeito, ao considerar o conceito de "atividade". Todavia, diferente do Idealismo, o sujeito considerado por Marx é incarnado num corpo sensível, e apreendido na sua dimensão social. Sobre o conceito de "atividade revolucionária", ela não deixa justamente por isso de ser preciso, pois faz justamente referência à relação do "aspecto ativo" sublinhado pelo Idealismo Alemão em referência à Revolução Francesa.Marx assume uma tese de Heine, que procura retomar a relação da Revolução Francesa com as análises de Kant, Schiller, Fichte e Hegel.

Com efeito, se em Marx nós podemos encontrar uma consideração do ser humano como um ser ativo, isto é, "um ser sensivelmente ativo na vida social", também não é menos verdade que Marx pensa o conceito de "atividade sensível" no interior de limites, de condicionamentos, conferindo a estes termos uma significação importante. Vimos que esses condicionamentos são apontados por Arendt através do mundo cotidiano dos objetos fabricados disponíveis ao uso, pela na ação comum e a vida corporal, e, enfim, na Terra como expressão máxima do condicionamento dos mortais $(\mathrm{CH}, \mathrm{p} .3)$. Marx tampouco vai deixar de enfatizar este aspecto, e com isto encerramos nossa comparação entre os dois autores.

É na Ideologia Alemã que Marx, em colaboração com Engels, vão articular uma "fenomenologia" do conceito de condição em conjunção com o conceito de "ser ativo" já explicado, que não deixa também de comportar uma série de correspondências com a perspectiva de Arendt quanto ao aspecto ao mesmo tempo activo e condicionado dos seres humanos. Em uma nota de rodapé da Ideologia Alemã acrescentada pelo editor do texto, Marx e Engels fazem referência ao conceito de "condições de existência, do seguinte modo: as "condições de existência" constituem "limitações", "determinações" para os indivíduos. Em outra passagem da Ideologia Alemã, ao lado da associação da ideia de condição à limitação ou determinação, é descrito que "Ces diferentes conditions, qui apparaissent d'abord comme conditions de l'auto-activation de soi". Este último conceito é semelhante ao conceito de "atividade" que aparece nas Teses sobre Feuerbach, com a diferença que Marx "acrescenta" "auto", com o propósito de referir-se a uma atividade reflexiva dada na relação de si a si mesmo em referência aos seus limites. Ao invés do conceito de "atividade sensível", cujo paradoxo consiste em articular o aspecto ativo e a determinação sensível dos sujeitos, Marx pensa na simbiose entre atividade e condição por meio do conceito de autoativação. Existe condição humana somente na medida em que nós temos indivíduos ativos, de modo que existe uma circularidade entre as condições de existência e as atividades humanas. As condições de existência pressupõem "o conjunto da atividade que é seu fundamento". O que significa que existe uma pressuposição entre "atividade humana" e as "condições" que lhes determinam. Mas é preciso não confundir esta circularidade com uma simples relação de correspondência. Marx e Engels pensam acerca da relação umbilical entre as condições postas (a maior de todas é a natureza que assegura a existência dos seres humanos) e as atividades pressupostas (trabalho e obra, como explica a Ideologia Alemã), mas esta identidade é cindida por uma contradição que é pensada historicamente a partir da relação entre os indivíduos e suas condições de existência. Para Marx, em conjunto com Engels, as condições de existência são sempre condições para os indivíduos, sem os quais a explicação da constituição das classes não é possível, num raciocínio clássico de Ricoeur (Ricoeur, 2005, pp. 140-141), em que pese sua tradução de Selbsbetatigung por "manifestação de si", uma vez que assim traduzido, um traço decisivo do conceito idealista de Selbsbetatigung é negligenciado, precisamente na sua relação com o conceito de condição: em primeiro lugar, a Selbsbetatigung se refere notadamente à ideia de autoactividade, de passagem à atividade, de realização de um ato, como já vimos Marx explicar nas $T F$. Em segundo lugar, uma relação estreita é estabelecida entre atividade e condição. $\mathrm{Na}$ Ideologia Alemã as condições de existência" são sempre quadros no interior dos quais os 
indivíduos se auto-ativam ou não, isto é, as condições de auto-activação dos indivíduos podem encontrar-se bloqueadas, o que Marx chama nos Manuscritos econômico-filosóficos de atividade alienada, isto é, atividade na qual o agente não é mais causa de si, mas causa para um Outro. Marx diz, "Ces diferentes conditions, qui apparaissent d'abord comme conditions de l'auto-activité, et plus tard comme entraves de celle-ci, forment dans toute l'évolution historique une suíte cohérente de modes d'échanges ..." (Marx, 1932, p. 61) Na medida em que pensa o conceito de condição como ativação ou bloqueio, portanto, sem o lastro de uma essência, Marx postula uma historicidade para as condições de existência dos indivíduos. Elas são dependentes dos modos de produção históricos, resultados da cristalização da "atividade de toda uma geração". Assim mesmo, ao mesmo tempo que admiti a contingência das condições, Marx apreende um movimento de universalização e de individualização das mesmas. "Les mêmes conditions, la même opposition, les mêmes intérêts devaient aussi, grosso mode, faire naître les même moeurs partout». (idem, p.61) No movimento de universalização das condições de existência os indivíduos são determinados por um mesmo denominador comum. E uma vez universalizadas, as condições de existência passam a ser apresentar separadas dos indivíduos, pois estão referidas nos seus interesses, e não mais nos costumes herdados do passado. Daí resulta que as forças produtivas não constituem mais sua expressão, termo que nós vimos se apresentar em Hegel, e também em Arendt, pois as forças reais somente se expressam agora no comércio e na interdependência dos indivíduos, de modo que a totalidade das forças produtivas toma uma forma objetiva, fazendo com que as condições de existência dos indivíduos não mais lhe pertençam. É assim que Marx pensa que a relação entre condições e atividade pode ser resignificada no vocabulário da alienação enquanto potência estrangeira que se descola das atividades dos indivíduos, expressas em um Outro. Em resumo, na Ideologia Alemã a questão consiste em saber se as condições de existência bloqueiam ou auto-ativam a atividade dos indivíduos; se as condições são potências estrangeiras, formas herdadas do passado relativamente à atividade dos indivíduos, ou condições para sua auto-ativação, o auto-desenvolvimento das suas capacidades. Ou o desenrolar das atividades pode ser bloqueado quando as condições se tornam um entrave para o livre desenvolvimento das atividades, quando as atividades não são desenvolvidas pelos indivíduos, mas por um Outro que se coloca como o garantidor das condições endereçadas aos indivíduos; ou então as condições de existência se tornam condições de possibilidade para que os indivíduos se auto-ativem. A alienação do objeto do qual o sujeito depende para atualizar suas capacidades ou disposições lhe abstrai da concretude material na qual estas são atualizadas, fazendo dele um sujeito abstrato. É subtraído da objetividade do mundo das relações sociais que em princípio que lhes facultaria sua livre disposição concreta.

\subsection{Em torno da $11^{a}$ TeSe SObre Feuerbach (III).}

Arendt parte de Aristóteles para criticar Heidegger e em seguida encontra Marx, autor com quem os seus conceitos passam a ser medidos. Ora, examinando as duas passagens fundamentais de $\mathrm{CH}$ em que Arendt discute Marx, à saber, na passagem concerne ao problema da inversão entre vida contemplativa e vida activa, e no capítulo sobre o conceito de trabalho, nós podemos dizer que a primazia do conceito de práxis ou atividade sobre o objeto ou condições de existência se encontram em ambos os autores, assim como a distinção entre obra e trabalho. O último ponto a ser observado, para concluirmos nossa perspectiva, diz respeito a relação de Arendt com a $11^{\circ} \mathrm{TF}$ e o problema da "realização ou fim da filosofia". Nesta tese Marx diz que "The philosophers have only interpreted the world ... the point, however, is to change it", e na frase "You cannot supersede [aufheben in the Hegelian triple sense of conserve, raise to a higher level, and abolish] philosophy without realizing it", nós encontramos a mesma orientação. (Arendt, 2005, p. 86). Antes de explicar o ponto de vista de Arendt, lembremos o de Heidegger segundo o qual Marx assinala o fim ou o acabamento da metafísica, e que após Marx o que nós teríamos seriam renascimentos epigonais. O tema da inversão entre filosofia, interpretação do mundo, e 
transformação (change), realização, se inscreve no interior desse acabamento ou finalização da metafísica hegeliana, e após este fim, a filosofia deve se voltar para "as coisas mesmas", para o mundo como horizonte da práxis. Já Arendt, leitora de Marx, afirma na obra $A$ Promessa da Política que na $11^{a} T F$ nós encontramos o tema da inversão entre vida activa e vida contemplativa na forma de uma afirmação da "dignidade da política", sua relevância para a reflexão filosófica, pois que marcada pela conversão da atualidade política em filosofia. Isto é, a inversão da contemplação dos filósofos, sua interpretação do mundo, pela ação revolucionária como transformação do mundo, implica uma afirmação ou "centralidade da política" para o pensamento, e não que nós devamos renunciar ao pensamento político pela sua realização como práxis. $\mathrm{Na} 11^{\mathrm{a}} \mathrm{TF}$, para Arendt, nós não encontramos "nem ... uma nova filosofia, não a filosofia, por excelência, de Marx ele mesmo, mas do auto-destino do homem como um filósofo tradicional" (idem, p. 87). Em resumo, com a inversão entre interpretação e realização, o que Marx modifica não é a filosofia, explica Arendt, "mas sua alegada impraticabilidade", "ele modifica a resignação do filósofo que não mais faz que encontrar um lugar para ele-mesmo no mundo, ao invés de modificar o mundo e fazer isto, por assim dizer, filosoficamente." A filosofia se encontra realizada quando ela intervém no curso das coisas de maneira filosófica, não sendo mais o apanágio de um único indivíduo, mas a teoria da transformação do mundo por uma coletividade. No seu comentário, Arendt vai em seguida opor este ponto de vista à perspectiva do ideal platônico dos filósofos que governam como Reis, afirmando que a $11^{\mathrm{a}}$ Tese "implica não o governo do filósofo sobre o homem, mas que todo homem pode tornar-se, como eles foram, filósofos.” (idem, p. 92.)

$\mathrm{Na}$ mesma explicação da $11^{\circ}$ Tese, Arendt expõe que a inversão da contemplação pela ação tomou forma em Marx pela inversão da filosofia da história de Hegel: "A consequência que Marx virou de cabeça-para-baixo a filosofia da história de Hegel era que a ação ou práxis, ao contrário da tradição inteira, era longe de ser considerada o oposto do pensamento, era a verdade e o real veículo do pensamento, e que a política, longe de estar infinitamente abaixo da dignidade da filosofia, era a única atividade que era inerentemente filosófica." (idem, p. 92) Marx não se encontra muito longe da perspectiva de Arendt de valorização filosófica da política, pondo de cabeça para baixo a filosofia da história de Hegel, (Arendt, $\mathrm{O}$ que é a história ). Igualar a práxis ao próprio pensamento, significa o abandono do tempo passado associado à contemplação filosófica, em direção ao tempo futuro, tempo da práxis humana. No comentário de Habermas, esta valorização da práxis em detrimento da teoria constitui uma espécie de temporalização da filosofia, e ocorreu "quando o espírito do tempo exerceu um poder sobre a filosofia, quando a consciência moderna do tempo rompeu a forma do pensamento filosófico", de agora em diante marcado pela experimentação do novo e abertura ao futuro. (Habermas, 2000, p. 74) Em outras palavras, o primado filosófico da práxis provém de uma temporalização política da filosofia, e isto ocorre, tomando agora a observação de Arendt sobre Marx na $11^{\mathrm{a}} \mathrm{TF}$, quando Marx vira de cabeça para baixo a filosofia da história de Hegel ao valorizar a práxis ou ação, de modo que a partir de então a política passa a ter uma "dignidade" para a teoria, não sendo mais dela dissociável como um veículo do pensamento, da filosofia.

Essa atmosfera intelectual de espiritualização da política segundo a qual a práxis é o veículo do pensamento, é parte do contexto filosófico e político de Marx na época da $T F$ nas "filosofias da ação" dos jovens hegelianos. Neste contexto (nota), o problema da inversão da contemplação pela ação vai procurar dar conta do esclarecimento da questão da "realização" da filosofia, a inversão de ordens entre o contemplar o passado e o agir político no presente. O primeiro esforço provém de A. von Cieszkowski, no seu Prolègomèes à l'historiosohie: a ação abole as cisões entre sujeito e objeto, interioridade e exterioridade, Espírito e Natureza, pois é "um fato absoluto". (Cieszkowski, 1973) Moses Hess sem dúvida é uma referência fundamental para a compreensão desta conceptualização da práxis como saída da filosofia, pois antecede com clareza a leitura de Arendt da $11^{\mathrm{a}}$ Tese segundo a qual a realização da filosofia não significa uma saída fora da filosofia, mas uma sacralização da vida política e social pelo pensamento, a "dignidade da política" para o pensamento. (Bensunçan, 1985, p. 176). O pensamento de Hess, que se refere inclusive à Cieszkowski, pretende deslocar-se da totalização hegeliana da história universal. Esta opera, segundo Hess, a partir do passado, 
mas o que importa é a direção ao futuro, o ultrapassamento do fechamento do passado, sobre a via da ação livre: “jusqu'à présent la philosophie ne se référait qu'à ce qui est, était et a été, et non à ce quis sera, si bien que l'on peu designer la philosophie allemande, et notamment dans as dernière phase, la philosophie hégélienne, comme une philosophie du passé." (idem, p. 176-8) A inversão da filosofia da história de Hegel pela valorização da práxis, na indicação fornecida por Arendt sobre Marx, encontra em Hess seu antecedente. Para Hess, abrir-se ao futuro significa apreender sobre o lugar da ação, da ação consciente, livre e voluntária, cuja base é a ação absoluta do espírito: "seul le fait denué de liberte, le factum, est suivi par la conscience, alors que l'action livre est précédée par elle ... C'est précisément la volonté qu engendre là l'action à la fois consciente et persistante, sans laquelle il ne saurait y avoir d'authentique liberte ni de vie morale." (idem, p. 176). Marcada por um esforço de ir além da forma abstrata e suprassensível, a filosofia da ação propõe um retorno aquém, na constituição do mundo por um ativismo da consciência e da vontade cuja fonte, também evocada por Cieszkowski, (Stathis Kouvélakis, 2014), é o conceito de "atividade" de Fichte, retomado também por Marx, como já visto. Para Hess, inverter a contemplação significa ultrapassar a filosofia em direção à ação, que nada deixa atrás de si a não ser a atividade. Ora, este primado da atividade que aparece na forma da negação ou realização da filosofia pela ação, é para Hess um ultrapassamento filosófico da filosofia: $\mathrm{O}$ primado da atividade é da ordem do espírito, e As Vinte e Uma Folhas, marco dessa filosofia da ação nos de 1842, serve de referência incontornável:

Actuellement, la philosophie de l'action ne doit afronter d'obstacles considérable nulle part plus que chez nous qui soufrons encore de cette universelle et médiévale maladie, de ces oppositions entre pratique et théorie, politique et religion, ici-bas et au-délà. Et cependant, la philosophie de l'action ne peut receboir son príncipe que de l'Allemagn. C'est seulement là où la philosophie en general est parvenue à son point culminant qu'elle peut se dépasser en passant à l'action. L'opposition de l'ici-bas et l'au-delà, née uniquement dans et par l'esprit, ne peut à son tour être dépassée, en son príncipe, que dans et par l'esprit. (Hess, apud Stathis Kouvélakis, p. 208; Bensussan, 1985, p. 51.)

Estas filosofias da ação são aquelas que nutrem a definição de Marx da práxis como uma atividade sensível, humana, real, objetivida-subjetiva, como diz a Tese 1, (TS, p. 51), que nos serviu de ponto de vista comparativo entre Arendt e Marx. Seu programa na forma de "teses" consistia em destacar a força prática dos homens, sua irredutibilidade ao pensamento, às ideias. O que significa que o conceito de inversão, funciona como um demarcador de um novo campo, visceralmente inverso à contemplação, pois mostra seus limites e demarca um campo novo chamado "filosofia da ação". E desta que parte Arendt, no fundo, em $C H$, ao inverter o primado da contemplação pelo da ação, tornando possível que a ação singular e social se torne objeto de investigação filosófica, não mais havendo assim uma oposição entre pensamento e ação, nem tampouco a sobreposição de um sobre o outro. De agora em diante é o primado do sujeito e da atividade prática dos homens, da atividade de um sujeito que age e sofre, pois que é ativo e passivo, que é fundamental para a "filosofia".

\section{CONCLUSÃo}

$\mathrm{Na}$ discussão dos conceitos de vida activa e condição humana em $\mathrm{CH}$ nós encontramos a influência de Aristóteles, Heidegger e Marx. No predomínio do uso e da obra sobre o trabalho e o consumo, nós encontramos a influência de Heidegger e Aristóteles. A articulação da obra com a condição mundana repõe a perspectiva de Ser e Tempo. É o mundo cotidiano do ser-aí que é acionado para estabelecer este nexo. Todavia, da mesma forma que em Heidegger, ele ainda é insuficiente para estabelecer o predomínio da práxis, daí porque Arendt retém a influência do conceito de energeia oriundo de Aristóteles, em oposição à desvalorização ainda renitente do mundo público-cotidiano pelo autor de Ser e Tempo, na medida em que Heidegger considera o agir como atividade de um sujeito 
autêntico separado dos demais seres humanos. O próximo passo de Arendt consiste em mobilizar este quadro teórico para criticar Marx, pois que o predomínio do trabalho é considerado uma condição da apolitia moderna, a política estando submetida aos imperativos das necessidades econômicas. Ora, alguns reparos devem ser feitos. Fundamentalmente, é necessário apreendermos corretamente o significado do conceito de inversão em Marx indicado por Arendt para entendermos o conceito de "práxis" em Marx, assim como a dupla significação do trabalho como produção de valor de uso, que corresponde ao conjunto da riqueza humana, e valor de troca, para significar a especificidade da produção capitalista, pois que a insistência de Arendt sobre a distinção o entre trabalho e obra recobre no fim das contas esta distinção. Arendt retoma o uso do corpo do escravo com o trabalho das mãos do artesão para explicitar esta distinção, pautando-se no horizonte clássico, e Marx o corpo produtivo do trabalhador no tempo da produção moderna em oposição do trabalho artesão. Enfim, se estivermos corretos ao colocar em equivalência a atividade da práxis enquanto constituinte do conceito de vida activa em Arendt com a atividade sensivel em Marx, então é justo considerarmos a partir da citação de Heidegger acima, sobre os renascimentos epigonais da filosofia da práxis, que Arendt constitui um destes renascimentos: o predomínio da "vida activa" sobre as condições ou limites da existência humana, corresponde a ênfase posta por Marx na práxis sobre o objeto. Enfim, Arendt parte do fato das atividades humanas serem localizadas ou condicionadas, e Marx do caráter condicionado da atividade sensível. Esse condicionamento implica naturalmente, nos dois autores, uma crítica do sujeito abstrato da atividade humana, pois visa infundir a vida activa no corpo sensível, pois é ao mesmo tempo corpo que trabalha, imaginação que produz e práxis política

Para terminar, apesar de insistir em uma correspondência de perspectivas e problemas entre Arendt e Marx, em particular quanto à valorização da práxis sobre o objeto, um ponto de desacordo deve ser destacado, e neste aspecto, Arendt está não somente em acordo com Marx, mas em desacordo com ele num ponto que testemunha contra sua perspectiva. O ponto de desacordo consiste em que esta igual valorização da práxis em Arendt e Marx se encadeia diferentemente com as necessidades humanas, isto é, com o trabalho como expressão do caráter condicionado da existência humana. Arendt parte da separação entre política e trabalho, pois que é o horizonte da pólis marcado pela separação e, a ligação - da liberdade do cidadão e do trabalho escravo que orienta sua apreensão do bios políticos, cujo referente teórico é a teoria de Aristóteles acerca da oposição da família e da pólis. Para Arendt, Marx apreende o aspecto ativo do homem apenas no trabalho, de modo que a operação de inversão deixa de lado os diferentes constituintes do conceito de vida activa. Como vimos, Marx não só põe a distinção entre valor de uso e valor de troca como fundamental, mas também, no que se refere ao agir, Marx parte do conceito de "atividade sensível", de "práxis", como versa as TF e a Ideologia Alemã. Todavia, Arendt e Marx encaminham diferentemente a relação entre o agir prático e suas condições ou limitações, e com este ponto nós encerramos nosso texto. Para explicá-lo, não farei mais do que seguir um comentário de Arendt sobre a $11^{a}$ Tese sobre Feuerbach, no qual pensamos se encontrar de maneira inequívoca a continuidade e a distância que os separa:

When Marx declared he no longer wanted to interpret the world but to change it, he stood, so to speak, on the threshold ofa new concept of Being and world, by which Being and world were no longer givens but possible products of man. But even he, when he declared that freedom was achieved through insight into necessity, beat a quick retreat into the old safety and thus gave back to man, who in losing his hold on the world had also lost his pride, a measure of dignity that was now of little use to him. (Arendt, 2002, p. 171)

Ora, é justamente este retorno em direção às necessidades humanas que para Marx é fundamental na práxis política moderna, de modo que entre a primeira etapa de transformação do mundo, onde o "ser" passa a ser o resultado do agir, em consequência da autonomia humana, como descreve Arendt, e seu encaminhamento em direção às necessidades humanas, a passagem é continua. É a partir desta "localização" das atividades humanas que devemos pensar o lugar da práxis política destacado por Arendt. O que 
significa que o sentido da política é a liberdade na perspectiva da capacidade de transformação das condições de existência humana, aquelas que impedem o homem de ser activo, reduzindo-o a simples passividade.

Para finalizar, vejamos o seguinte quadro comparativo sobre $\mathrm{CH}$, se bem que extrapolado em alguma medida no que concerne ao aprofundamento de certos temas que não abordei com exaustividade. Não tratamos da questão da técnica em Heidegger na sua relação com a análise da forma-trabalho em Ernst Junger. Naturalmente que esta questão implicaria uma discussão sobre a tese de Arendt acerca do fim do trabalho com os processos automativos no dignóstico do final do Prólogo de $C H(\mathrm{CH}$, p. 5), uma reflexaõ que não deixa de possuir uma relação com a análise da Maquinaria e da Grande Indústria de Marx em $O$ Capital e nos capítulos do Grundrisse sobre a automação. Como esta discussão levarme-ia um pouco longe demais, sua exposição teórica fica para um outro trabalho. Para os demais pontos, a finalidade didática do quadro abaixo espera cumprir seu papel. Seu objetivo é expor o quanto os conceitos de Arendt em $\mathrm{CH}$ se constituem entre Heidegger e Marx.

\begin{tabular}{|c|c|c|c|c|c|}
\hline \multicolumn{2}{|c|}{ Heidegger } & \multicolumn{2}{c|}{ Arendt } & \multicolumn{2}{c|}{ Marx } \\
\hline Atividade & Condição & Atividade & Condição & Atividade & Condição \\
\hline Técnica & Terra & Trabalho (corpo) & Vida & $\begin{array}{c}\text { Trabalho (corpo) } \\
\text { Força de trabalho }\end{array}$ & $\begin{array}{c}\text { Tempo social da } \\
\text { produção }\end{array}$ \\
\hline $\begin{array}{c}\text { obra-uso- } \\
\text { instrumento }\end{array}$ & ser-no-mundo & $\begin{array}{c}\text { Obra-uso, } \\
\text { instrumento }\end{array}$ & ser-no-mundo & $\begin{array}{c}\text { Obra-uso e } \\
\text { consumo }\end{array}$ & Natureza \\
\hline resolução situada & Mundo público & Práxis-reversão & $\begin{array}{c}\text { Mundo-público, } \\
\text { atividade } \\
\text { revolucionária }\end{array}$ & Práxis-reversão & $\begin{array}{c}\text { Relações sociais, } \\
\text { atividade } \\
\text { revolucionária }\end{array}$ \\
\hline ser-aí, existência & $\begin{array}{c}\text { eternidade, } \\
\text { ontologia } \\
\text { tradicional }\end{array}$ & Vida activa & $\begin{array}{c}\text { Vida contemplativa } \\
\text { - Vida do Espírito }\end{array}$ & Práxis, mudança & $\begin{array}{c}\text { Interpretação, } \\
\text { Ideologia }\end{array}$ \\
\hline
\end{tabular}

\section{REFERÊNCIAS}

ARENDT, H. A Condição Humana. 12 ed. rev. RJ: Forense, 2014

ARENDT,H. Essays of Understanding: 1930-1954. 1 ed. NY: Harcout, 2005

ARISTÓTELES. Ética a Nicômaco. Brasília: 2009,

A. VON Cieszkowski. Prolègomèes à l'historiosohie. Berlim, 1838, trad. De M. Jacob, paris, Ed. Champ Libre 1973

HABERMAS, J. O Discurso Filosófico da Modernidade. SP: Martins Fontes, 2000.

HEIDEGGER, M. Etre et Temps. Paris: Gallimard, 1986.HEIDEGGER, M. HEIDEGGER, M. Questions III e IV. Paris: Gallimard, 1976.

HEIDEGGER, M. A origem da obra de arte. Lisboa: Edições 70, 2004.

HESS, Moses. La philosophie de l'action, In. Moses Hess, la philosophie, le socialisme : 1836-1845 / Gérard Bensussan; en annexe, trois textes de Moses Hess, Socialisme et communisme, Philosophie de l'action. Bruxelas: Olms, 1995.

MARX, K. Le Capital, Livro 1. Paris: PUF, 1993.

MARX, K. Manuscrits economique-philosophiques de 1844. Tradução de Franck Fishback. Paris: Vrin, 2007. MARX, K. Les Thèses sur Feuerbach. Commentaires de Georges Labica. Paris: PUF, 1987.

MARX, K e ENGELS, F. L'Idéologie Allemande. Paris: Ed. Sociales, 1930.

POSTONE, Moishe. Tempo, trabalho e dominação social. São Paulo: Boitempo, 2014.

RICOEUR, P. Idéologie et utopie. Paris: Seuil, 2005.

ROCKMORE, Tom. Marx, Fichte and the German Philosphy. 1980, p.

TAMINIAUX, J. Heidegger and the Project of Fundamental Ontology. State University of New York Press, 
1991.

KOUVÉLAKIS, S. Philosophie et Revolution de Kant à Marx. La Fabrique Editions, 2014.

TAYLOR, Charles. Hegel and the Philosophy of Action, Arto Laitinen \& Constantine Sandis (eds.), Hegel on Action. Palgrave-Macmillan, 2010, pp. 01-41.

VILA, D. Arendt and Heidegger - The Fate of the Political. Princenton, New Jersey, University Press, 1996.

190

\section{Notas}

1 Como diz Heidegger a propósito de Marx e do problema do fim da filosofia: "Avec le retournement de la métaphysique, déjà accompli avec Karl Marx, c'est la plus extreme possibilite de la philosophie qui se trouve atteinte." Questions, III e IV, Gallimard, Paris, p. 284. Nós retomaremos esta questão quando discutirmos a questão da "inversão" em Marx na sua relação com Arendt.

2 No resumo de Taminiaux, "tudo se passa como se o bios téôrètikos devorasse e regesse a praxis inteira." op. cit. p. 171.

3 K. Marx, Le Capital, Livro 1, Paris PUF, p. 207. Arendt não considera o segundo aspecto da determinação do trabalho descrito por Marx como processo de valorização. Cf. K. Marx, op. cit., p. 221. O primeiro aspecto é resumido assim por Marx: "C'est pourquoi le travail en tant que formateur de valeurs d'usage, en tant que travail utile, est pour l'homme une condition d'existence indépendante de toutes les formes de société, une nécessité naturelle éternelle, mediation indispensable au m'tabolisme qui e produit entre l'homme et la nature, et donc à la vie humaine." p. 48, op. cit.

4 Em A Ideologia Alemãa, Marx faz referência à distinção entre trabalho e obra. Cf. op. cit. p. 46.

5 Ver as observações de Franck Fischbach na sua tradução e comentários aos Manuscrits economiquephilosophiques de 1844, Paris, Vrin, pp. 17-18. 